\title{
細胞集団浸透性ポリマーの開発
}

東北大学 大学院工学研究科 材料システム工学専攻*1), 東北大学 大学院医工学研究科 ${ }^{* 2)}$

山本雅哉 ${ }^{* 1,2)} \cdot$ 森本展行 $^{* 11}$

\section{Development of a spheroid-permeable polymer}

Spheroids have attracted much attention in medical research as a tool to understand both disease mechanisms and drug actions in culture. Cell-cell and/or cell-extracellular matrices interactions seen in spheroids allow cells to mimic in vivo cellular microenvironments, resulting in recapitulating in vivo-like cell functions in culture. However, the microenvironments could also function as a barrier to deliver drugs to cells in spheroids. To tackle this drawback, a sulfobetaine polymer was developed as a spheroid-permeable polymer. In this article, the enhanced anticancer activity of anticancer drugs by conjugation with the spheroid-permeable polymer was introduced.

スフェロイドは、疾患メカニズムや薬物作用を培養系で理解するためのツールとして、医学研究で 注目されている。スフェロイドにおける細胞と細胞、細胞と細胞外マトリックスの相互作用は、体内 の細胞微小環境を模倣することを可能とし、その結果、体内の細胞機能を培養系で再現することがで きる。しかし、この細胞微小環境は、スフェロイド內の細胞へ薬物を送達する際の障壁としても機能 する。この問題を解決するために、スフェロイドに対する細胞集団浸透性ポリマーとしてスルホベタ インポリマーを開発した。本稿では、スルホベタインポリマ一修飾による抗がん作用の増強について 紹介する。

Masaya Yamamoto ${ }^{* 1,2)} \cdot$ Nobuyuki Morimoto $^{* 11}$

Keyword: cell aggregate, spheroid, sulfobetaine polymer, spheroid-permeable polymer

\section{1.はじめに}

スフェロイドは、複数の細胞からなる集合体 $($ 細 胞集団)である。1種類の細胞からなるスフェロイ ドもあれば、異なる種類の細胞から構成されるス フェロイドもある。スフェロイド内の細胞は、体内 と同様に、隣り合う細胞や細胞外マトリックスなど からなる細胞微小環境と相互作用して機能してい る。このため、スフェロイドは、通常の単層培養さ れた細胞と比較すると、より体内に近い細胞機能が 期待される。このようなスフェロイドの特徵から、 近年、スフェロイドが再生医療や創薬などへ応用さ れている。一方、後述するように、スフェロイド内

\footnotetext{
${ }^{* 1)}$ Department of Materials Processing, Graduate School of Engineering, Tohoku University

${ }^{* 2)}$ Graduate School of Biomedical Engineering, Tohoku University
}

では物質の透過性が制限されるため、細胞培養での 維持も含めて、さまざまな技術が必要不可欠である。 ここでは、スフェロイドについて概説するとともに、 筆者らの細胞集団浸透性ポリマーに関する研究につ いて紹介する。

\section{2. スフェロイドとは}

スフェロイドに関する研究は、さまざまなアプ ローチからはじまっている。代表的なアプローチと して、肝臓から単離した初代肝細胞を利用したハイ ブリッド型人工肝臓や薬物研究があげられる。すな わち、初代肝細胞を、集合体化させたスフェロイド として培養するアプローチである。例えば、肝細胞 に含まれる解毒に関与するシトクロム P450 (CYP) 酵素は、スフェロイドの場合、単層培養よりも高発 
現されていることが報告されている1)。

近年、発生生物学、細胞生物学、分子生物学 の進歩によって、スフェロイドは、神経幹細胞 $(\text { neurosphere })^{2)}$ 、胚性幹細胞 $(\mathrm{ES} \text { 細胞 })^{3)}$ 、人工多 能性幹細胞 $(\mathrm{iPS} \text { 細胞 })^{4)}$ などの幹細胞から目的の細 胞を分化誘導する方法として注目されはじめた。例 えば、細胞懸濁液を培養容器の蓋にぶら下げるハン ギングドロップ法は、液滴内で重力により沈降した ES細胞あるいは iPS 細胞からなる集合体 (embryoid body:EB)を形成させる方法である。さらに、近年、 個体の発生過程を模倣した培養法により、EB から 臓器機能の一部をもつミ二器官 (オルガノイド)を誘 導できるようになってきており、より高度な細胞機 能をもつスフェロイドとして注目されている。この ようなオルガノイドに関する研究の進展とともに、 幹細胞からスフェロイドを作製する技術も進歩して いる。例えば、幹細胞の自己複製能を活用して、フ ラスコ内で覺拌することにより、スフェロイドを作 製することもできるようになっている ${ }^{5)}$ 。また、最 近、細胞接着性の低い低接着性培養容器が開発され ており、スフェロイドを容易に作製できるように なっている(図1)。これらのスフェロイドをマトリ ゲルなどの細胞外マトリックス内で培養することに よって、より高次の細胞機能を実現することが可能 になりつつある。

一方、幹細胞のみならず、がん細胞に対しても、 細胞を集合体化して培養する方法が注目されてい る。がん細胞は、ソフトアガーゲル中において、1 つの細胞から増殖した複数の細胞からなるコロニー を形成する能力を有している。このコロニー形成能 に基づき、がん細胞も容易にスフェロイドを形成す ることができる。さらに、集合体化のみならず、が ん細胞の細胞機能も幹細胞と同様に変化する。例え ば、ヒト肝がん細胞株である HepG2では、単層培
養と比較して、スフェロイド培養では多剂耐性遺伝 子(MDR1)の発現が充進し、抗がん剤の1つである ドキソルビシン $(\mathrm{Dox})$ の $50 \%$ 阻害濃度 $\left(\mathrm{IC}_{50}\right)$ が 8 倍 以上になることが知られている ${ }^{6)}$ 。すなわち、Dox の抗がん活性が、単層培養と比較してスフェロイド では低下する。このように、がん細胞は培養条件に より細胞機能が変化する。一方、がん治療薬に関す る研究では、主に、単層培養されたがん細胞が使用 される。したがって、体内の細胞微小環境と著しく 異なる場合、期待された抗がん活性が得られない可 能性がある。このため体内の細胞微小環境を模倣し たスフェロイドを用いたがん治療研究が注目されて いる。

\section{3. 細胞集団浸透性}

スフェロイドを用いた研究における課題の1つが スフェロイドの培養技術である。スフェロイドを培 養すると、細胞間の密着結合や細胞と細胞との間に 細胞外マトリックスが沈着する場合がある。これら は体内の細胞微小環境を模倣するために必要不可欠 である。一方、スフェロイドが大きくなれば、必要 となる栄養や酸素の供給ならびに老廃物の排出が阻 害される。例えば、膵蔵においてインスリンを産生 する膵 $\beta$ 細胞からなる細胞集団 (ランゲルハンス島) では、細胞あたりの栄養や酸素の消費量、栄養や酸 素のランゲルハンス島内の拡散などを考慮すると、 ランゲルハンス島表面から約 $200 \mu \mathrm{m}$ 程度までしか 細胞が生存できないことが見積もられている7 なわち、スフェロイドを再生医療などに利用する場 合には、内部の細胞にまで栄養や酸素を供給するた めのバイオリアクターが必要不可欠である(図2)。

がん治療研究では、細胞死が主な抗がん活性の指 標となるため、がん細胞スフェロイドにおける細胞

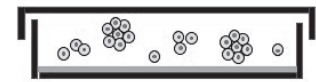

低接着プレート （細胞懸濁）

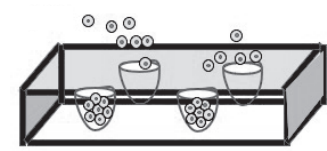

マイクロウェル

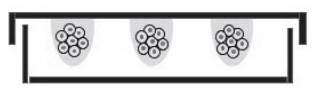

ハンギングドロップ

図1 スフェロイド作製法の例 


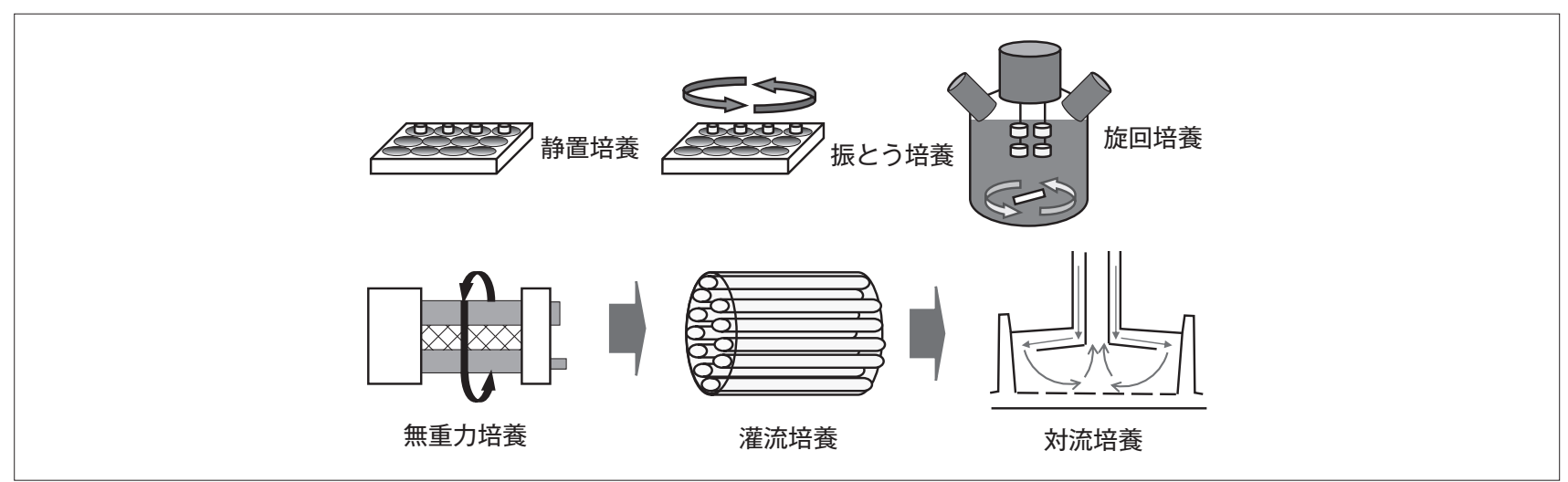

図2 バイオリアクターの例

死の原因が、抗がん活性であるのか、あるいは単な る栄養や酸素の供給不足であるのか、これらを区別 する難しさがある。また、細胞に到達する薬物量も 単層培養された細胞と比較して低くなることが予想 され、薬物の抗がん活性に加えて、薬物の細胞集団 浸透性も考慮する必要がある。

細胞集団に薬物を浸透させるルートとして、細胞 を通り抜けさせる場合と細胞間を通り抜けさせる場 合のいずれか、あるいはこれら両方の3つが考えら れる。細胞を通り抜けさせる場合、細胞内へのド ラッグデリバリーシステム (DDS) を考える必要が ある。ここで、リポソーム製剤や高分子ミセルなど のナノキャリアが細胞内に取り达まれる経路は、主 に、(1)細胞膜直接透過、(2)エンドサイトーシス、お よび(3)膜融合である。一方、細胞間を通り抜けさせ る場合、細胞間の密着結合や細胞間への細胞外マト リックスの沈着を考慮する必要がある。難治性のが んにおいて、細胞外マトリックスの沈着がナノキャ リアの浸透性を著しく阻害することを示唆する知見 も示されつつあるが8)、細胞外マトリックスがナノ キャリアの浸透性に与える影響の解明には、今後の 研究が待たれる。このような状況の中、がん組織浸 透性をもつ高分子薬剤として、ホスホベタインポ リマーの1つである MPC (2-methacryloyloxyethyl phosphorylcholine) と BMA (butyl methacrylate) と の共重合体 (poly ( MPC-co-BMA))が Ishihara らに よって報告された ${ }^{9)}$ 。MPCポリマーは、細胞膜中 に存在しているホスホリルコリン基をもつベタイン ポリマーであり、さまざまな医療機器で生体適合性 を示す ${ }^{10)}$ 。poly(MPC-co-BMA)が、がん組織浸透
性を示すメカニズムは詳細に解明されていないが、

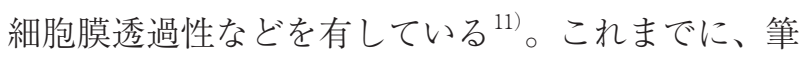
者らは、スルホ基を有するスルホベタインポリマー が、同様に細胞膜透過性を有することを報告してき $た^{11 \sim 13)}$ 。

\section{4. ベタインポリマー}

ベタイン (betaine) とは、正電荷と負電荷を同一 分子内の隣り合わない位置にもち、分子全体として は電荷電位をもたない分子内塩である。このような 分子内塩を有するモノマーからなる高分子をべ夕 インポリマーと呼ぶ。一般に、アニオンやカチオ ンなどの電荷をもつ高分子電解質は、水中で水の 構造を強く形成／破壊するが、ベタインポリマー は、その効果が比較的穏やかである。さらに、べ夕 インポリマーは、それぞれのイオン性基の種類と数 によって分類される。例えば、リン酸基を有する ホスホベタイン(例えば MPC ポリマー(PMPC))、 カルボキシ基を有するカルボベタイン（例えば poly [(2-dimethacryloyloxyethyl) ammonium methyl carbanate](PDMAMC))、スルホ基を 有するスルホベタイン (例えば poly-[3-dimethyl (methacryloyloxyethyl)ammonium propane sulfonate](PDMAPS))があげられる ${ }^{14)}$ 。

ベタインポリマーは、側鎖間で双極子－双極子相 互作用により分子内や分子間で会合し、さらに疎水 基を導入することにより、自己組織的にベシクルな どを形成する(図3 $)^{14,15)}$ 。さらに、ベタインポリマー のアンチファウリング性により、非標的タンパク質 


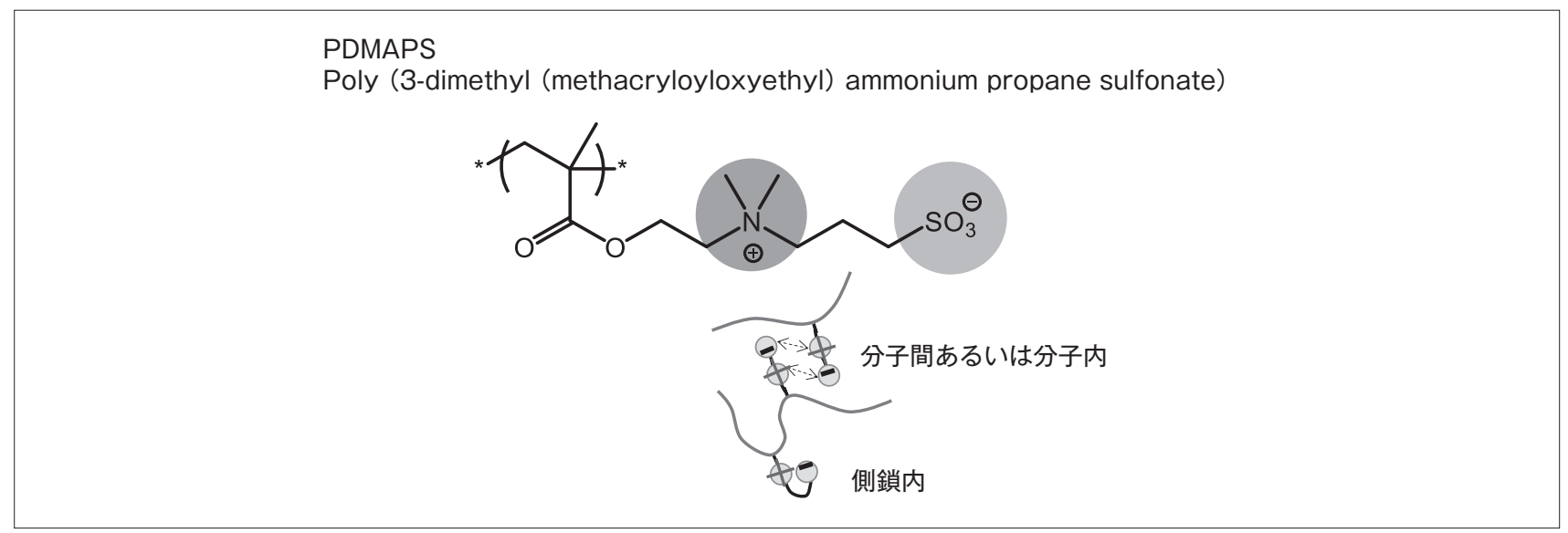

図3 ベタインポリマーの双極子-双極子相互作用による会合

や細胞の吸着を防ぐ効果が期待できる。そのため、 医療デバイスへの応用や DDS材料として研究が進 められている ${ }^{15)}$ 。例えば、poly[2-(methacryloyloxy) ethyl phosphorylcholine]-block-poly [2(diisopropylamino) ethyl methacrylate]は、 pH応 答性を示し、Dox やパクリタキセルを内包した 状態で扁平上皮がん細胞内に特異的に内在化さ れること ${ }^{16)}$, poly (lactide-co-glycolide)-block-poly (carboxybetaine)は、カルボベタインのもつカルボ キシ基を利用することによって、蛍光分子や標的リ ガンドで修飾された診断ナノキャリアを容易に調 製できること年)、poly ( $\varepsilon^{-}$-caprolactone $)$-block-poly ( $(N, N$-diethylaminoethyl methacrylate $)-\operatorname{ran}-\left(N^{-}\right.$ (3-sulfopropyl) $-N$-methacryloxyethyl- $N, N$-diethy lammoniumbetaine))が細胞内に内在化し、アポトー シスを誘発できることなどがあげられる ${ }^{18)}$ 。

ベタインポリマーの1つであるスルホベタイン ポリマーは、双極子 - 双極子相互作用が強く、高 い粒子形成能をもつことに加え、PMPC と同様に、 生体適合性や非タンパク質吸着能に優れているこ とが報告されている ${ }^{19 \sim 22)}$ 。さらに、カチオン性ブ ロックや $\mathrm{pH}$ 応答性ブロックなどの共重合体が合成 され、機能性キャリアとして DDSへ応用されてい る $^{23,24)}$ 。

\section{5. スルホベタインポリマー}

筆者らは、これまで、スルホベタインポリマー として、PDMAPSに着目してきた。PDMAPS
は、合成が容易であり、低細胞毒性、上限臨界 共溶温度 (UCST) 型の温度応答性、イオン性ポリ マーとの複合体形成などの特性を有する。しかし、 PDMAPS には、双極子一双極子相互作用により水 中で凝集するという問題がある。そこで、筆者らは、 PDMAPS と同様に生体適合性をもち、親水性が高 いノニオン性の poly (ethylene glycol) (PEG)との共 重合体を合成した。

PEG 鎖が修飾された連鎖移動剂を用いて得られ たブロック共重合である PEG-block-PDMAPS は、 純水中で自己組織的に $1 \mu \mathrm{m}$ 程度の多層型マイクロ スフェアを形成し、UCST型の温度応答性を示した。 また、この UCST は塩濃度によって制御可能であっ た ${ }^{25)}$ 。さらに電場の印加、およびずり応力の付加に よりマイクロスフェア間の融合 - 解離など、多重の 刺激応答制御を可能とした $(\text { 図4 })^{26)}$ 。また、UCST 型の温度応答性を利用することによって、オリゴ DNA の内包と、内包されたオリゴDNA をマイク ロスフェア間で交換できることも確認している27)。

PEG methyl ether methacrylate(PEGMA) と のランダム共重合体P (DMAPS-ran-PEGMA (P

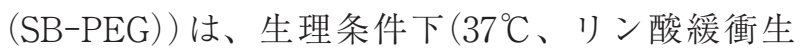
理食塩水(PBS))に执いて自己組織的にナノサイズ の粒子を形成した。ヒト子宮頸がん細胞(HeLa細 胞)に対し、P(SB-PEG)を作用させたところ、P (SB-PEG) は細胞毒性を示さず、核やミトコンドリ アを含む細胞全体に分布することを見出した。また、 $\mathrm{P}(\mathrm{SB}-\mathrm{PEG})$ はエンドサイトーシスが阻害される低 温条件 $\left(4^{\circ} \mathrm{C}\right)$ でも取り込まれ、逆に、エンドサイトー 

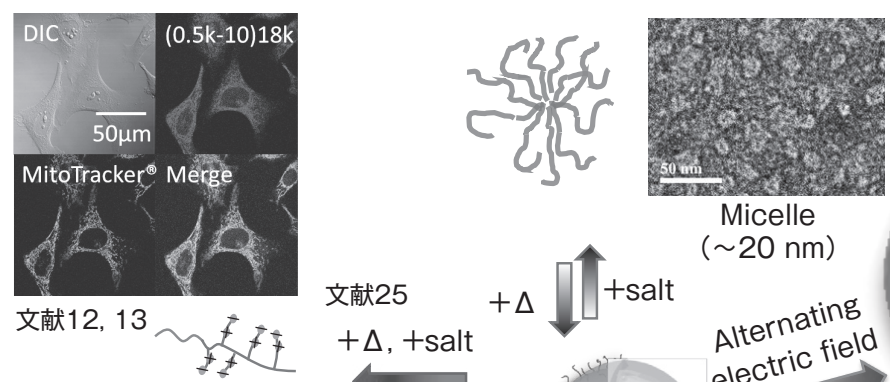

$(\sim 20 \mathrm{~nm})$
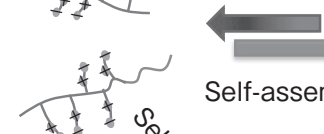

Self-assembly

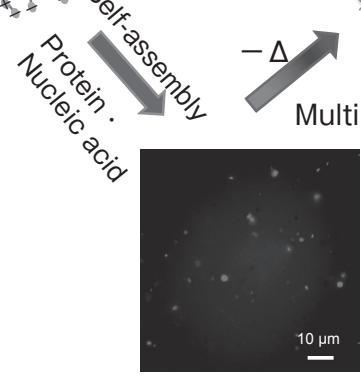

Multilayered microspheres $(1 \sim 10 \mu \mathrm{m})$

Nucleic acid-incorporating multilayered microspheres

文献27

図4 ベタインポリマーの双極子-双極子相互作用による会合
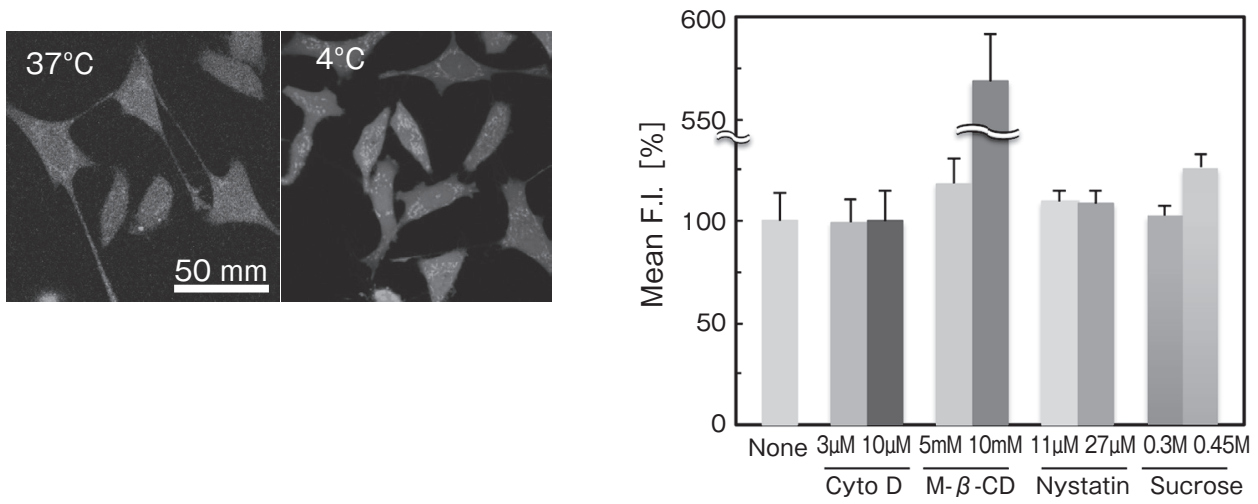

図5 P (SB-PEG)の HeLa細胞内分布とエンドサイトーシス阻害剂による取り込み量変化

シスの各種経路の阻害剂添加条件において、取り込 み量の減少が認められないことから、エンドサイ トーシス非依存的に細胞内に取り込まれていること も明らかにした(図5) ${ }^{28)}$ 。

\section{6. スルホベタインポリマーの細胞集団浸透性}

脳腫瘍の1つである膠芽腫 (glioblastoma) は、悪性 神経膠腫の $82 \%$ 占めている。A-172細胞は、脳の 神経細胞を支える神経膠細胞 (星状細胞、未分化グ
リア)が腫瘍化した細胞から樹立された細胞株であ る ${ }^{29)}$ 。この A-172細胞を、低細胞接着性の U-bottom 96-well plate(Prime Surface, Sumitomo Bakelite Co. Ltd., Tokyo, Japan)に1500細胞/well の濃度で播種 後、4日間培養することにより、直径約 $300 \mu \mathrm{m}$ の 丸い形状をしたスフェロイドが得られる。得られた A-172スフェロイドは、E-cadherin を全体に発現し ており、その内部は低酸素状態であった。

赤色蛍光を示す抗がん片Doxにより修飾された $\mathrm{P}(\mathrm{SB}-\mathrm{PEG}) 、 \mathrm{Dox}-\mathrm{P}(\mathrm{SB}-\mathrm{PEG})$ を用いて、A-172 
スフェロイドにおける $\mathrm{P}(\mathrm{SB}-\mathrm{PEG})$ の細胞集団浸透 性を評価した。共焦点レーザー走査顕微鏡を用い て、培養液を $20^{\circ} \mathrm{C}$ に維持しながらスフェロイドの 赤道付近をタイムラプス観察したところ、Dox-P (SB-PEG)は、添加直後にスフェロイド表面で確認 され、その後、徐々にスフェロイド内部へ浸透し た。蛍光強度のラインプロファイルから、Dox $-\mathrm{P}$ (SB-PEG)は、添加60 分以内にスフェロイドの中心 に到達したことがわかった(図6)。一方、コントロー ルとして用いた $\mathrm{P}(\mathrm{SB}-\mathrm{PEG})$ 修飾していない Dox (Free Dox)では、スフェロイド表面付近にDoxの 弱い蛍光を認めた。この蛍光は、添加30分後に初 めて確認された。また、いずれのコントロールの場 合でも、添加120分後であっても、スフェロイド表 面から 1 ～2層の細胞までしか到達していないこと がわかった。以上の結果は、P $(\mathrm{SB}-\mathrm{PEG})$ が細胞集 団浸透性をもつことを示唆している。
7. 細胞集団浸透性スルホベタインポリマーで修 飾した抗がん剂のがん細胞スフェロイドに対 する抗がん活性

$\mathrm{P}(\mathrm{SB}-\mathrm{PEG})$ の細胞集団浸透性を活用して、ス フェロイド内部への抗がん剤のデリバリーについて 検討した。抗がん剂として、DNA 合成を阻害する Dox と熱ショックタンパク質の1つである HSP90 を阻害する夕ネスピマイシン $(17 \mathrm{AAG})^{30)}$ とを用い た。A-172スフェロイドの体積は、抗がん剂非存在 下で培養 10 日後には約 2.3 倍に増加するが、Dox-P (SB-PEG) 処理したスフェロイドの体積は、Dox-P (SB-PEG) 添加濃度 $10 \mu \mathrm{M}$ 以上で低下し、増殖阻害 が認められた。しかし、Free Doxでも同等の増殖 阻害が認められた(図7)。Free Dox と同等の増殖 阻害となった原因として、Dox-P(SB-PEG) はス フェロイド内の細胞に認められたが、そのスフェ ロイド内の局所濃度が $\mathrm{IC}_{50}$ 濃度よりも低くなった 可能性や、スフェロイド外層の細胞にFree Dox が

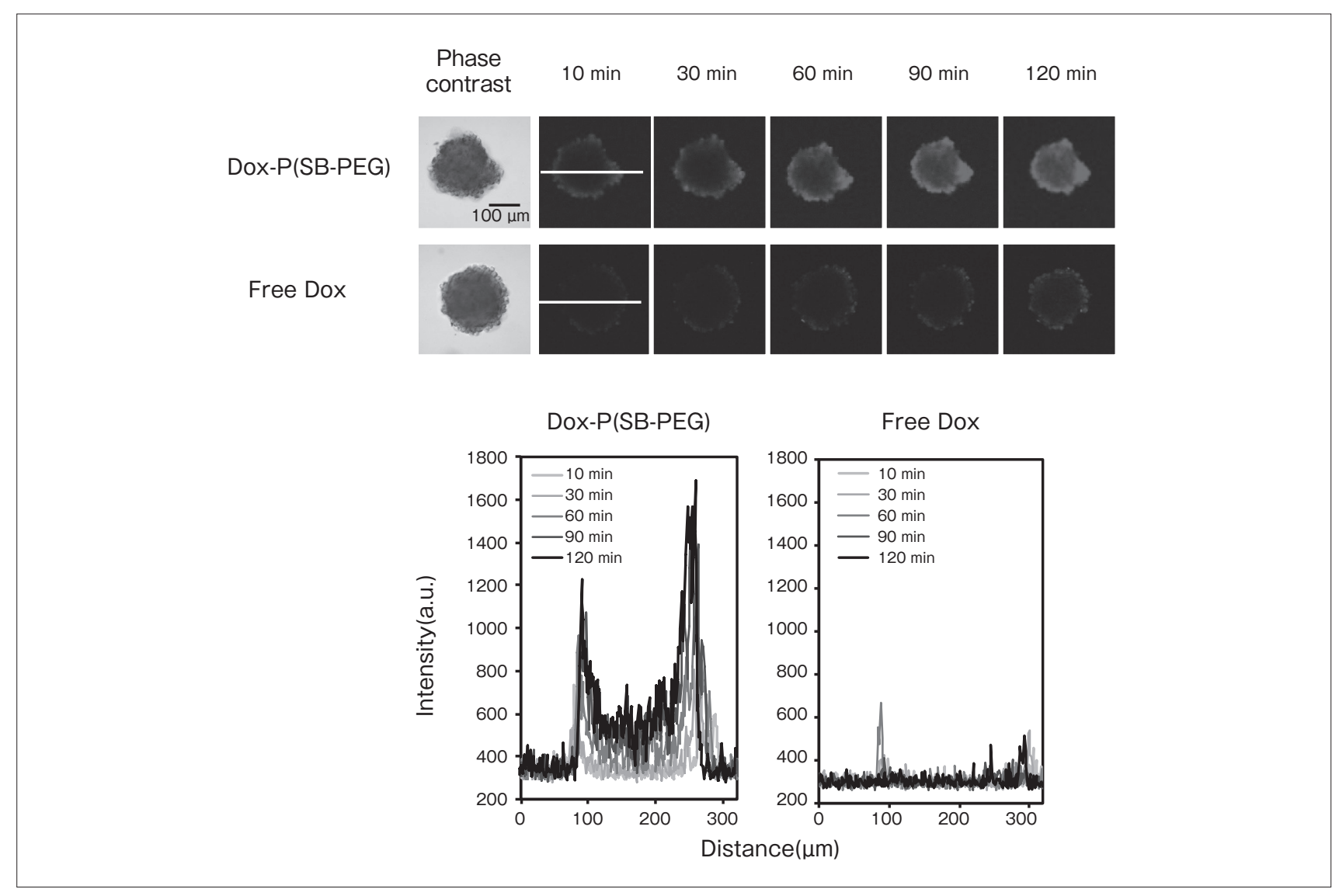

図6 A-172スフェロイドへの P (SB-PEG)の細胞集団浸透性 


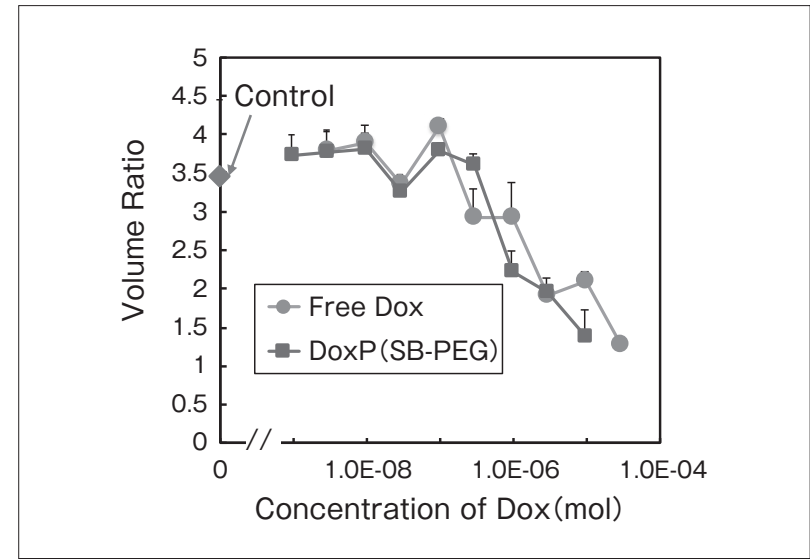

図7Ｄox-P(SB-PEG)によるA-172スフェロイドの増殖阻害

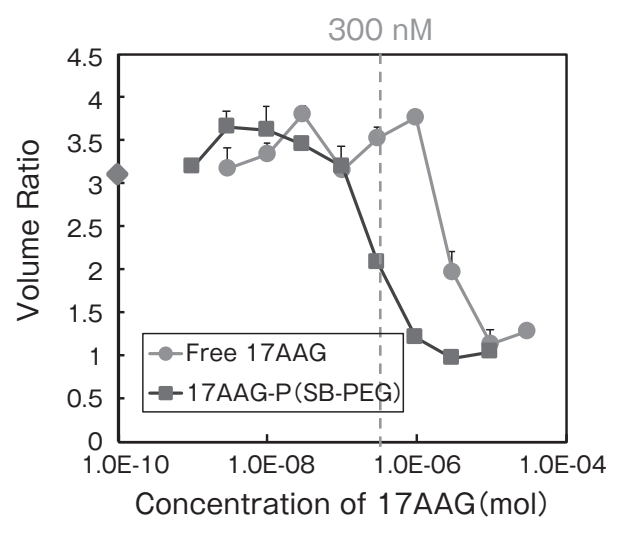

図8 17AAG-P (SB-PEG)による A-172 スフェロイドの増殖阻害

作用した可能性などが示唆された。また、Dox-P (SB-PEG)が細胞内のミトコンドリアに集積するこ とから、細胞内分布が影響した可能性も考えられる。

一方、P(SB-PEG) 修飾した $17 \mathrm{AAG}(17 \mathrm{AAG}-\mathrm{P}$ (SB-PEG))の A-172スフェロイドに対する増殖阻 害について評価したところ、17AAG-P(SB-PEG) は、P(SB-PEG) 修飾していない $17 \mathrm{AAG}$ (Free $17 \mathrm{AAG})$ と比較して有意な増殖阻害を示した。Free $17 \mathrm{AAG}$ は $3 \mu \mathrm{M}$ 以上で $\mathrm{A}-172$ スフェロイドの増殖 を顕著に阻害した。また、P $(\mathrm{SB}-\mathrm{PEG})$ 修飾により $17 \mathrm{AAG}$ の効果は約10倍になった(図8)。さらに、 Live/Deadアッセイを行ったところ、17AAG-P (SB-PEG)を添加した場合、スフェロイド全体に 死細胞に由来する赤色蛍光が認められた(デー夕省 略)。この結果は、17AAG-P (SB-PEG)が A-172 久 フェロイド内部へ浸透し、細胞死を誘導したことを 示唆している。

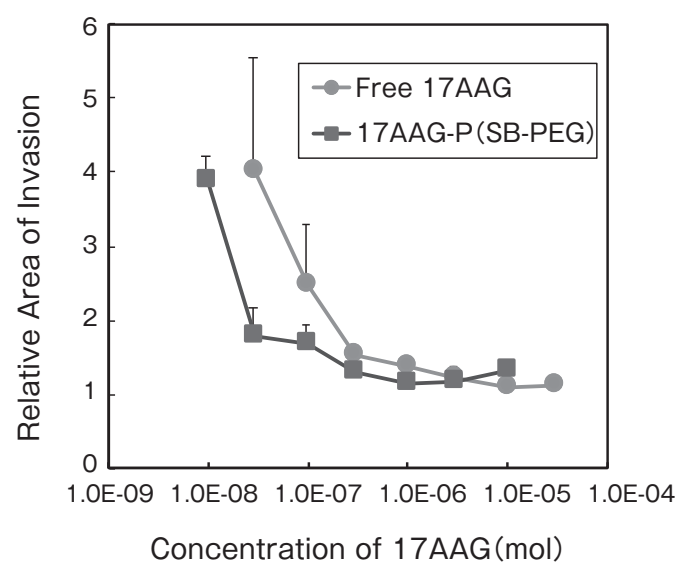

図9 17AAG-P (SB-PEG)によるA-172スフェロイドの3D マトリッ クスへの浸潤阻害

Matrigel に封入したA-172スフェロイドを用い て、3Dマトリックスへの浸潤アッセイを行った。 その結果、17AAG-P (SB-PEG)の非存在下では、1 日目に明らかな浸潤が観察され、3日目の浸潤面積 は0日目の面積に比べて15.8倍に増加した。一方、 $17 \mathrm{AAG}-\mathrm{P}(\mathrm{SB}-\mathrm{PEG})$ の添加により、この浸潤は Free 17AAG と比較して有意に抑制された(図9)。

以上のことから、P(SB-PEG)の細胞集団浸透性 は、スフェロイドに対する抗がん剤の作用機序を 含めた研究への応用が可能であることが示唆され た ${ }^{30)}$ 。

\section{8. おわりに}

本稿では、がん細胞スフェロイドに対するスルホ ベタインポリマーの細胞集団浸透性について概説し た。一方、がん細胞のみならず、iPS 細胞などの幹 細胞から誘導されたスフェロイドがオルガノイド として創薬へ応用されている。さらに、疾患特異 的iPS細胞を利用すれば、より病態に近いモデルを 用いた創薬も可能になりつつある。細胞集団に特有 の薬物の低い浸透性は、これらの創薬におけるデメ リットであり、今後、ますます、細胞集団浸透性 DDS技術の開発が期待される。 


\section{文献}

1) Wu F.J., et al., Cell Transplant., 8, 233-246 (1999)

2) Doetsch F., et al., Cell, 97, 703-716 (1999)

3) Thomson J.A., et al., Science, 282, 1145-1147 (1998)

4) Takahashi, K., et al., Cell, 131, 861-872 (2007)

5) Otsuji T.G., et al., Stem Cell Reports, 2, 734-745 (2014)

6) Oshikata A., et al., J. Biosci. Bioeng., 111, 590-593 (2011)

7）岩田博夫, 生体組織工学, 産業図書, 215-217 (1995)

8) Tanaka H.Y., et al., Cancer Sci., 109, 2085-2092 (2018)

9) Kamei T., et al., Cancer Sci., 102, 200-205 (2011)

10) Ishihara K., et al., J. Biomed. Mater. Res. A, 107, 933-943 (2019)

11) Goda T., et al., Langmuir, 36, 9977-9984 (2020)

12) Morimoto N., et al., Sci. Rep., 8, 1128 (2018)

13) Morimoto N., et al., Macromol. Biosci., 20, e2000205 (2020)

14) Erfani A., et al., Biomacromolecules, 21, 2557-2573 (2020)

15) Kobayashi M., et al., J. Biomater. Sci. Polym. Ed., 25, 1673$1686(2014)$
16) Helen C.E., et al., Mol. Pharm., 11, 1176-1188 (2014)

17) Zhiqiang C., et al., Angew. Chem. Int. Ed., 49, 3771-3776 (2010)

18) Jun C., et al., Biomaterials, 35, 4517-4524 (2014)

19) West L.S., et al., Biomaterials, 25, 1195-1204 (2004)

20) Yang J., et al., Langmuir, 31, 9125-9133 (2015)

21) Ren P.F., et al., Langmuir, 31, 5851-5858 (2015)

22) Zhang Z., et al., Langmuir, 22, 10072-10077 (2006)

23) Dai F., et al., Biomaterials, 32, 628-638 (2011)

24) Chen C.Y., et al., Macromol. Rapid Commun., 35, 1534-1540 (2014)

25) Morimoto N., et al., Macromol. Rapid Commun., 35, 103-108 (2014)

26) Morimoto N., et al., RSC. Adv., 5, 14851-14857 (2015)

27) Morimoto N., et al., Colloids Surf. B: Biointerfaces, 128, 9499 (2015)

28) Morimoto N., et al., Biomacromolecules, 17, 1523-1535 (2016)

29) Sanchez-Martin C., et al., Front. Oncol., 10, 1177 (2020)

30) Morimoto N., et al., Biomacromolecules, 21, 5044-5052 (2020) 